\title{
Role of Zakat in Sustainable Development Goals
}

\author{
Salman Ahmed Shaikh \\ Universiti Kebangsaan Malaysia \\ Abdul Ghafar Ismail \\ Universiti Islām Sultan Sharif Ali Negara Brunei Darussalam
}

\begin{abstract}
In this paper, we explore the potential of the institution of Zakāt to meet the development challenges, especially in the Muslim world. We discuss the interlinkages between the institution of Zakāt and Maqasid-al-Shari'ah. We also discuss the economic potential and effects of Zakāt by reviewing theoretical and empirical studies. Finally, we also provide our analysis which suggests that Zakät can play an important role in meeting sustainable development goals related to poverty, hunger, global health and well-being, quality education, decent work and economic growth and income inequality.
\end{abstract}

Keywords: Zakāt, Sustainable Development Goals, Poverty, Inequality

JEL Classification Code: E6, H2, H3

\section{INTRODUCTION}

Zakāt is a compulsory obligation in the faith of Islām to pay a certain part of surplus wealth to the specified beneficiaries every year. As per Islāmic principles, every year, $2.5 \%$ of wealth subject to Zakāt has to be paid by the Muslims to the 8 specified heads of beneficiaries and causes. Zakāt is compulsory to be paid by every Muslim who owns sufficient amount of wealth. In Islāmic jurisprudence, if a Muslim owns an equivalent monetary sum of Nisāb, he has to pay $2.5 \%$ of surplus wealth above the Nisāb every year.

Zakāt is an important institution in an Islāmic economic framework for poverty alleviation and economic welfare. The poverty rate is generally higher in Muslim majority countries, a great number of whom are located in Asia and Africa. Food insecurity and hunger is also a major problem in Muslim majority countries. Due to lack of a sustainable source of subsistent level of incomes, Muslim population faces heightened poverty.

One of the major goals of the future development agenda is to end poverty and hunger. Therefore, in this paper, we explore how much potential this institution of Zakāt has to meet the development challenges, especially in the Muslim world.

The paper proceeds as follows. In the next section, we discuss the interlinkages between the institution of Zakāt and Maqasid-al-Shari'ah. Then, in Section 3, we discuss the economic potential and effects of Zakāt by reviewing theoretical and empirical studies. Finally, in Section 4, we discuss how the institution of Zakāt can help in achieving sustainable development goals. 


\section{ZAKĀT AND MAQASHID-E-SHARI'AH}

In the Islāmic knowledge and institutional framework, there are five foundational goals, also known as 'Maqasid-al-Shari'ah'. These include protection of faith, life, progeny, intellect and wealth. In one of the supplications of the Prophet Muhammad (pbuh), $\mathrm{He}$ (pbuh) sought refuge from disbelief and poverty together. Poverty and destitution can make a person vulnerable in faith and may engender the perception that his way out of poverty is dependent on others. A person facing poverty can have lesser chances of exercising free will in choosing the right means to fulfill the essential needs. Thus, to reduce poverty with the aim of making people come out of the vulnerable state of Imān is an important part of Maqasid-e-Shari'ah. If the institution of Zakāt can help in alleviating poverty and help the poor people, then it can contribute in promoting the Maqasid-e-Shari'ah, which is to protect and preserve the faith and avoid it to become vulnerable.

Poverty can result in loss of life from lack of essential nutrition and basic lifesaving medication. Therefore, if Zakāt helps a person to afford essential food intake and essential life-saving medicines, then it can help in saving lives, which is again an important component of Maqasid-eShari'ah.

Infectious diseases can cause epidemic which can result in mass scale loss of lives and endanger the survival of entire human communities and other species in a particular affected geography. Likewise, fear of poverty can result in some people getting desperate and taking lives of themselves and their dependents. Poverty can become a vicious cycle and affects generations after generations. Thus, if the institution of Zakat can enable people to get out of poverty trap, it will be consistent with protecting human progeny, which is an important part of Maqasid-e-Shari'ah.
Lack of essential nutrients can cause stunting and affect intellectual capabilities. Thus, if the institution of Zakāt can enable people to afford essential life's nutrients, then it will help in the healthy nourishment of children and make them more productive in future. Thus, the institution of Zakāt can help by making people afford essential nutrition and basic education.

Zakāt is a means of purifying wealth. When a person fulfills the obligation to pay Zakāt, he is able to purify his/her wealth. It may seem that the wealth decreases by payment of Zakāt, but, at the societal level, it helps in wealth circulation which eventually benefits everyone in terms of economic activity and strengthening of social safety. The spiritual benefit of Zakāt is even more significant. Zakāt helps a Muslim to achieve spiritual fulfillment by pleasing Allah and help a person to obtain Barakah in the all-encompassing sense of contentment and promise of greater rewards in this life and the life hereafter.

Thus, we see that the institution of Zakāt is an important institution in the Islāmic framework, which has interlinkages with Maqasid-e-Shari'ah and potential to play a key socio-economic role in the society as well.

\section{ECONOMIC POTENTIAL OF ZAKĀT}

Shaikh (2016) estimates potential Zakāt collectible in 17 member countries of Organization of Islāmic Cooperation (OIC). He finds that Zakāt to GDP ratio exceeds Poverty Gap Index to GDP (PGI-GDP) ratio except in 3 countries with poverty line defined at $\$ 1.25$ a day. He shows that the aggregate resources pooled together from the potential Zakāt collection in 17 OIC countries will be enough to fund resources for poverty alleviation in all 17 OIC countries combined. 
In the early empirical literature on welfare potential of Infaq (charity) to alleviate poverty in Pakistan, Malik et al. (1994) use microdata to establish that Infaq (charity) does have a significant impact on reducing poverty gap. In a more recent study, Azam et al. (2014) in an empirical study for Pakistan establish that Zakāt significantly enhances the welfare of the households. M. Akram \& Afzal (2014) in an empirical study for Pakistan argue that Zakāt disbursement among the poor, needy, destitute, orphans and widows has played a significant role in poverty alleviation. Their results show that there is an inverse relationship between poverty and Zakāt disbursement both in the short run and in the long run.

Using aggregate data for Malaysia, Suprayitno et al. (2013) find that Zakāt distribution has a positive, but small impact on aggregate consumption. Hence, Zakāt distribution should not be limited to the consumption needs, but should also cover other forms of monetary aid that can generate a continuous flow of income for Zakāt recipients. In another recent study, Abdelmawla (2014) argue based on empirical evidence using aggregated data for Sudan that Zakāt along with educational attainment significantly reduced poverty in Sudan.

In another empirical study for Bangladesh, Hassan \& Jauanyed (2007) estimate that Zakāt funds can replace the government budgetary expenditures ranging from 21\% of Annual Development Plan (ADP) in 1983-84 to $43 \%$ of ADP in 20042005. For Malaysia, Sadeq (1996) finds that about $73 \%$ of the estimated potential Zakāt collection will be needed annually to change the status of hard-core poor households to a status of non-poor households in Malaysia. Ibrahim (2006) contends in an empirical study for Malaysia that Zakāt distribution reduces income inequality. His analysis reveals that Zakāt distribution reduces poverty incidence, reduces the extent of poverty and lessens the severity of poverty. Firdaus et al. (2012) estimate the potential of Zakāt in Indonesia by surveying 345 households. Their results show that Zakāt collection could reach $3.4 \%$ of Indonesia's GDP, which can help in reducing poverty to a large extent.

Some other studies also show the comparative potential of Zakāt as a superior tool for poverty alleviation among other poverty alleviation institutions. Debnath et al. (2013) assess the effectiveness of Zakāt as an alternative to microcredit in alleviating poverty in Bangladesh. Through the Propensity Score Matching (PSM) technique, the study reveals that the impact of Zakāt scheme has proven to be greater than the microcredit programs. Besides that, the study also highlights that Zakāt scheme significantly increases both income and expenditure of the recipients in comparison to the microcredit programs.

Some studies like Nadzri et al. (2012) recommend integrating the various poverty alleviation and redistribution tools for creating synergies. The effectiveness of Zakāt institutions may improve by collaborating with other institutions such as Microfinance institutions. Shirazi (2014) suggests that the institutions of Zakāt and Waqf (charitable trust) need to be integrated into the poverty reduction strategy of the Islāmic Development Bank (IDB) member countries. The proceeds of these institutions should be made as part of their pro-poor budgetary expenditures. Hassan (2010) suggests a model which combines Islāmic Microfinance with two traditional Islāmic tools of poverty alleviation such as Zakāt and Waqf (charitable trust) in an institutional setup. Hassan (2010) argues that the poor borrowers will have less debt burden as their capital investments will be 
partly met by funds from Zakāt that does not require any repayment.

Finally, Norazlina \& Rahim (2011) identify that there are many types of programs that could be funded by Zakāt such as providing education for the poor, the establishment of schools, vocational training and rehabilitation for Zakāt recipients to make them more productive, establishment of agriculture and cottage industries, provision of fixed asset and equipment to small business projects, provision of working capital, building of low-cost housing and providing medical treatment and health care.

\section{SUSTAINABLE DEVELOPMENT GOALS}

The Sustainable Development Goals (SDGs) as successor to Millennium Development Goals (MDGs) represent a broader intergovernmental agreement to foster action on broad-based development encompassing economic development, human development and environmental sustainability.

There are 17 broad goals in which several targets had been set which are to be achieved by 2030 . We find that in at least 7 goals, the institution of Zakāt is highly important, especially in the Muslim majority countries.

Table 1. Comparison of Socio-Economic Indicators across Country Groups

\begin{tabular}{|c|c|c|c|}
\hline Indicators & $\begin{array}{c}\text { High } \\
\text { Income }\end{array}$ & $\begin{array}{l}\text { Middle } \\
\text { Income }\end{array}$ & $\begin{array}{c}\text { Muslim } \\
\text { Countries }\end{array}$ \\
\hline \multicolumn{4}{|l|}{ Economic } \\
\hline GDP Per Person Employed (Constant 2011 PPP\$) & 76,507 & 29,631 & 40,341 \\
\hline Poverty Ratio at PPP \$1.90 a Day (\% of Population) & 0.56 & 5.95 & 24.58 \\
\hline \multicolumn{4}{|l|}{ Education } \\
\hline Literacy Rate (\% of Adult Population) & 98.46 & 93.22 & 73.46 \\
\hline Net Enrolment Ratio in Primary (\%) & 96.92 & 92.34 & 85.55 \\
\hline \multicolumn{4}{|l|}{ Health } \\
\hline Hospital Beds (Per 1,000 People) & 5.18 & 3.37 & 1.98 \\
\hline Improved Sanitation Facilities (\% People with Access) & 97.14 & 81.85 & 64.53 \\
\hline Improved Water Source (\% People with Access) & 99.28 & 91.89 & 82.04 \\
\hline
\end{tabular}

Source: World Development Indicators, 2015

Since the goals are ambitious and the time-frame set for these goals is short, it is important that all-encompassing efforts are undertaken involving all sorts of institutions to make the largest leap forward. It is especially crucial for countries that are much behind the targets and need considerable effort and resources to pull themselves up to meet the targets. In Table 1, we show the state of development indicators in the Muslim majority, non-Muslim majority middle income and non-Muslim majority high-income countries. It clearly shows that
Muslim countries on average have to travel much more distance in achieving the development targets as compared to middle income and high-income countries.

Religious institutions which have a socio-economic character can also be employed in creating synergistic efforts towards achieving the sustainable development goals, especially in Muslim majority countries. The first sustainable development goal is to have no poverty by 2030. If we look at the institution of Zakāt, we find that the payer of Zakāt and the 
receiver of Zakāt belong to two different income classes. The payer of Zakāt is nonpoor with surplus wealth above Nisāb. On the other hand, the receiver of Zakät is usually a poor person with no surplus wealth above Nisāb. Thus, the threshold wealth of Nis $\bar{a} b$ makes a distinction between the payer and receiver and helps to achieve targeted income and wealth transfer to the people who are usually the poor people.

Since this redistribution is based on wealth rather than income, it can achieve the redistribution objectives more effectively and consistently since wealth fluctuates much less than income over the business cycles. Metwally (1983) argues that Zakāt has a wider base and it is applicable to both the incomes and the wealth. He emphasizes that the Zakāt system has an inbuilt mechanism to reach the right targets in terms of Zakāt collection and disbursement. This ensures increasing the propensity to consume more emphatically and quickly.

Furthermore, the accumulated wealth can be much more than the single period income, especially in the high net worth individuals of the society. That is why, in the absence of broad-based wealth taxes and loopholes in taxing off-shore wealth, the progressive income taxes alone have been unable to reduce income inequality and wealth redistribution. Hartman (2002) cites the case of US economy and argues that the progressive taxes were designed to reduce income inequality. But during the last four decades, while the share of income taxes levied on the upper tenth of incomes rose $15 \%$, the after-tax income share of the remainder of incomes declined by $13 \%$.

Oxfam reports that 8 individual persons have as much wealth as bottom $50 \%$ of the entire global population. Their combined wealth is $\$ 426.2$ billion as of end2016. As per World Bank, there are 767 million people below the poverty line of $\$ 1.90 /$ day. It means that poverty gap is
$\$ 531.9$ billion $(1.90 \times 767,000,000 \times 365)$ per year. Comparing the wealth owned by only the richest 8 persons ( $\$ 426.2$ billion) and the total global poverty gap funding requirement ( $\$ 531.9$ billion), one can see how redistribution of wealth can help in pooling poverty alleviation funds.

The second sustainable development goal is to end hunger. According to Food and Agricultural Organization (FAO), there are approximately 800 million people who suffer from hunger and are food insecure in their routine lives. Most of the poor countries lack basic resources to kick-start growth and to invest in health and education. The mere scientific solutions to health and education issues solve the supply side problem, but not the demand side problem since these essential services are produced and marketed in the global market economy on a commercial basis. If only $70 \%$ of the people in a country can afford to pay the market price of food, then for whom should the food be produced, i.e. the $70 \%$ of those who can afford or the $100 \%$ The answer by market economy where price mechanism reigns supreme is that it is quite possible to have market equilibrium at a price where only the $70 \%$ non-poor could afford food and $30 \%$ remain unserved and unfed unless they get charity or government's support. Thus, the redistribution of resources is vital to enhance income as well as the capacity to earn sustainable incomes, which requires income support programs, basic health and education as well as microfinance to build small enterprises.

According to The Hunger Project, 2.4 billion people do not have adequate sanitation and each day, nearly 1,000 children die due to preventable water and sanitation-related diarrheal diseases. It is partly because sanitation is not good business as compared to cellular services and life's other comforts and luxuries. Food and Agriculture Organization estimates that 
food per capita availability has increased since the 1970s, but still close to 800 million people suffer from hunger (Pingali, 2002). The institution of Zakāt could help in providing income support to the poor people who are food insecure due to lower and unsustainable incomes.

Another important sustainable goal is to have good health and well-being. Nearly 50 percent of the people living in extreme poverty are 18 years old or younger. This goes on to show that a significant portion of our global population would not have a fair start to achieve socio-economic mobility. Thus, proper nourishment, basic medicines and vaccinations are necessary to avoid illhealth, stunting and loss of capacities for independent productive living in adulthood. Some life-saving medicines cost less than a dollar, but they are underprovided due to commercial reasons. Unless effective redistribution happens, the purchasing power cannot be enhanced which is vital to afford even the basic necessities today, such as food, water and medicines.

The sustainable development goal of quality education is vital for achieving permanent poverty exit, enhancement of skills and capacities, and to ensure upward social mobility. The financial institutions can come to the rescue once the people are able to hold enough assets and skills for the enterprise. But, much before that, people require survival and human capital development in the early stage of life. There are mosque-based schools in the Muslim majority countries which effectively channelize Zakāt funds to ensure basic religious and secular education. Effective administration and management of the Zakāt funds can help in scaling up the benefits in terms of strengthening institutions to create synergistic effects.

Another important sustainable development goal is gender equality. The institution of Zakāt is completely neutral to gender in terms of its principles of rules regarding payment and receipt of Zakät. The Zakāt funds can be paid to the women and to institutions which are working for the wellbeing of women, such as maternity homes and schools for girls, for instance.

Decent work and economic growth is the most vital sustainable development goal to realize a sustainable reduction in poverty and in ensuring upward socio-economic mobility. On one hand, Zakāt from endowment surplus households (those having higher wealth than Nisāb) to the endowment deficient households can help in providing income support and affordability for skills enhancement programs. Zakāt could also be used to provide funding for education and health institutions, thereby contributing to human capital development which can provide decent work. On the other hand, the institution of Zakāt would ensure circulation of wealth in the productive enterprise, thereby directing capital to go in the real sector of the economy rather than sitting idle in the hands of the wealthy individuals.

The most important issue which is universally faced in the world is the rise in income inequality. It is universal since even the developed countries have higher income inequality. Piketty (2014) writes that $60 \%$ of the increase in US national income in the 30 years after 1977 went to just the top $1 \%$ of the earners.

In Table 2, we give a numerical example of wealth redistribution under the Zakāt system. The example would illustrate how the institution of Zakāt could help in reducing income inequalities. Suppose we have an interest free economy that comprises 10 rich people each having wealth of $\$ 1,010$. We also assume that there are 100 poor people each having wealth of $\$ 2$. Let us suppose that the Nis $\bar{a} b$ amount in this interest-free economy is $\$ 10$. Column 2 shows the aggregate wealth of rich people. 
Column 3 shows the wealth transferred from the rich to the poor in each year. Column 4 shows the aggregate wealth of poor people after wealth transfer.

For simplicity, we suppose perfect wealth equality between the people in each of the group. For the sake of highlighting the effect of wealth redistribution of wealth transfers, we assume that income is generated randomly in this interest-free economy with no interest based lending allowed. Furthermore, we assume that income earned is consumed in that period to enable us to focus our attention on the wealth redistribution effect of Zakāt in an interest-free economy. Column 5 shows the wealth multiple in each year for the two groups.

It can be seen that after around 27 years, the wealth multiple will drastically go down from 101 to almost 1 for the two groups as a whole. Column 6 shows the wealth multiple per person. It can be seen that wealth multiple will become only 5 after 27 years from the initial value of 505 . Eventually, the wealth recipients will become ineligible for Zakāt receipts and rather will become part of the Zakāt payer group.

Table 2. Numerical Simulation of Wealth Redistribution under Zakāt System

\begin{tabular}{|c|c|c|c|c|c|}
\hline Year & $\mathbf{W}_{\mathbf{R}}$ & $\begin{array}{c}\text { Wealth Transfer } \\
\text { (R to P) }\end{array}$ & $\mathbf{W}_{\mathbf{P}}$ & $\begin{array}{c}\mathbf{W}_{\mathbf{R}} \text { to } \mathbf{W}_{\mathbf{P}} \\
\text { Multiple }\end{array}$ & $\begin{array}{c}\mathbf{W}_{\mathbf{R}} \text { to } \mathbf{W}_{\mathbf{P}} \\
\text { Multiple Per } \\
\text { Person }\end{array}$ \\
\hline 0 & $10,100.00$ & & 100.00 & 101.00 & 505.00 \\
\hline 1 & $9,850.00$ & 250.00 & 350.00 & 28.14 & 140.71 \\
\hline 2 & $9,606.25$ & 243.75 & 593.75 & 16.18 & 80.89 \\
\hline 3 & $9,368.59$ & 237.66 & 831.41 & 11.27 & 56.34 \\
\hline 4 & $9,136.88$ & 231.71 & $1,063.12$ & 8.59 & 42.97 \\
\hline 5 & $8,910.96$ & 225.92 & $1,289.04$ & 6.91 & 34.56 \\
\hline 6 & $8,690.68$ & 220.27 & $1,509.32$ & 5.76 & 28.79 \\
\hline 7 & $8,475.92$ & 214.77 & $1,724.08$ & 4.92 & 24.58 \\
\hline 8 & $8,266.52$ & 209.40 & $1,933.48$ & 4.28 & 21.38 \\
\hline 9 & $8,062.36$ & 204.16 & $2,137.64$ & 3.77 & 18.86 \\
\hline 10 & $7,863.30$ & 199.06 & $2,336.70$ & 3.37 & 16.83 \\
\hline 11 & $7,669.21$ & 194.08 & $2,530.79$ & 3.03 & 15.15 \\
\hline 12 & $7,479.98$ & 189.23 & $2,720.02$ & 2.75 & 13.75 \\
\hline 13 & $7,295.48$ & 184.50 & $2,904.52$ & 2.51 & 12.56 \\
\hline 14 & $7,115.60$ & 179.89 & $3,084.40$ & 2.31 & 11.53 \\
\hline 15 & $6,940.21$ & 175.39 & $3,259.79$ & 2.13 & 10.65 \\
\hline 16 & $6,769.20$ & 171.01 & $3,430.80$ & 1.97 & 9.87 \\
\hline 17 & $6,602.47$ & 166.73 & $3,597.53$ & 1.84 & 9.18 \\
\hline 18 & $6,439.91$ & 162.56 & $3,760.09$ & 1.71 & 8.56 \\
\hline
\end{tabular}




\begin{tabular}{|l|l|l|l|l|l|}
\hline 19 & $6,281.41$ & 158.50 & $3,918.59$ & 1.60 & 8.01 \\
\hline 20 & $6,126.88$ & 154.54 & $4,073.12$ & 1.50 & 7.52 \\
\hline 21 & $5,976.20$ & 150.67 & $4,223.80$ & 1.41 & 7.07 \\
\hline 22 & $5,829.30$ & 146.91 & $4,370.70$ & 1.33 & 6.67 \\
\hline 23 & $5,686.07$ & 143.23 & $4,513.93$ & 1.26 & 6.30 \\
\hline 24 & $5,546.42$ & 139.65 & $4,653.58$ & 1.19 & 5.96 \\
\hline 25 & $5,410.26$ & 136.16 & $4,789.74$ & 1.13 & 5.65 \\
\hline 26 & $5,277.50$ & 132.76 & $4,922.50$ & 1.07 & 5.36 \\
\hline 27 & $5,148.06$ & 129.44 & $5,051.94$ & 1.02 & 5.10 \\
\hline
\end{tabular}

Source: Author's Computations

\section{CONCLUSION}

In this paper, we explored the potential of the institution of Zakāt to meet the development challenges, especially in the Muslim world. Muslim countries on average have to travel much more distance in achieving the development targets as compared to middle income and highincome countries. Since the goals are ambitious and the time-frame set for these goals is short, it is important that allencompassing efforts are undertaken

\section{REFERENCES}

Abdelmawla, M. A. (2014). "The Impacts of Zakāt and Knowledge on Poverty Alleviation in Sudan: An Empirical Investigation (1990-2009)", Journal of Economic Cooperation and Development, 35(4), $61-84$.

Azam, M.; Iqbal, N. \& Tayyab, M. (2014). "Zakāt and Economic Development: Micro and Macro Level Evidence from Pakistan", Bulletin of Business and Economics, 3(2), 85 - 95.

Debnath, S. C.; Islām, M. T. \& Mahmud, K. T. (2013). "The Potential of Zakāt Scheme as an Alternative of involving all sorts of institutions to make the largest leap forward. We discussed the economic potential and effects of Zakāt by reviewing theoretical and empirical studies. We also provided our analysis which suggests that Zakât can play an important role in meeting sustainable development goals related to poverty, hunger, global health and well-being, quality education, decent work and economic growth and income inequality.

Microcredit to Alleviate Poverty in Bangladesh", $9^{\text {th }}$ International Conference on Islāmic Economics and Finance, QFIS, Doha, Qatar.

Hassan, M. K. \& Jauanyed, M. K. (2007). "Zakāt, External Debt and Poverty Reduction Strategy in Bangladesh", Journal of Economic Cooperation, $28(4), 1-38$.

Hassan, M. K. (2010). "An Integrated Poverty Alleviation Model Combining Zakāt, Awqaf and Microfinance", in Seventh International Conference-The 
Tawhidi Epistemology: Zakāt and Waqf Economy, Bangi, Malaysia.

Ibrahim, P. (2006). "Economic Role of Zakāt in Reducing Income Inequality and Poverty in Selangor", PhD Thesis, Universiti Putra Malaysia.

M. Akram, M. \& Afzal, M. (2014). "Dynamic Role of Zakāt in Alleviating Poverty: A Case Study of Pakistan", University Library of Munich, Germany.

Malik, S. J.; Hussain, M. \& Shirazi, N. S. (1994). "Role of Infaq in Poverty Alleviation in Pakistan", The Pakistan Development Review, 33(4), $935-952$.

Metwally, M. M. (1983). "Fiscal Policy \& Resource Allocation in Islām”, Islamabad: Institute of Policy Studies.

Nadzri, F. A.; A. Rahman, R. \& Omar, N. (2012). "Zakāt and Poverty Alleviation: Roles of Zakāt Institutions in Malaysia", International Journal of Arts and Commerce, 1(7), $61-72$.

Norazlina A. W. \& A. Rahim, A. R. (2011). "A Framework to Analyse the Efficiency and Governance of Zakāt Institutions", Journal of Islāmic Accounting and Business Research, 2(1), $43-62$.

Piketty, T. (2014). "Capital in the Twentyfirst Century", New York: Harvard University Press.

Pingali, P. (2002). "Reducing Poverty and Hunger: The Critical Role of Financing for Rural Development, Food \& Agriculture. In International Conference on Financing for Development, March, 2002.

Sadeq, A. H. M. (1996). "Ethico-Economic Institution of Zakāt: An Instrument of Self Reliance and Sustainable Grassroots Development", IIUM
Journal of Economics and Management, 12(2), 47 - 69.

Shaikh, S. A. (2016). "Zakāt Collectible in OIC Countries for Poverty Alleviation: A Primer on Empirical Estimation". International Journal of Zakāt, 1(1), 17 - 35 .

Shirazi, N. S. (2014). "Integrating Zakāt and Waqf into the Poverty Reduction Strategy of the IDB Member Countries", Islāmic Economic Studies, 22(1), pp. 79 - 108.

Suprayitno, E., Kader, R. A., \& Harun, A. (2013). "The Impact of Zakāt on Aggregate Consumption in Malaysia", Journal of Islāmic Economics, Banking and Finance, $9(1), 39-62$.

World Bank Group (2012). "World Development Indicators 2012”. World Bank Publications.

Salman Ahmed Shaikh

Universiti Kebangsaan Malaysia

salman@siswa.ukm.edu.my

Abdul Ghafar Ismail

Universiti Islām Sultan Sharif Ali Negara

Brunei Darussalam

ghafar.ismail@unissa.edu.bn 